\title{
ALTERNATIVE ACCESS, MINING AND HOISTING FOR UNDERGROUND DEPOSITS
}

Summary. It is proposed to consider a new access, mining and hoisting system for underground deposits, as an alternative to the commonly used decline or vertical shaft access. The proposed system offers fundamental improvements in gathering of exploration data, reduction of capital expenditure and significant savings in mine operating costs. The cost reductions are achieved through: 1 . Superior ore body definition by Supersucker winzing on ore prior to the commencement of capital development. 2. Considerable reduction of capital development in waste. 3. Full capitalisation on all benefits of a raisebored excavation. 4 . Introduction of rubber tyred skip and rubber tyred Mine Rapid Response Vehicle. 5. Introduction of simplified ore handling system and reduction of underground mobile diesel fleet. 6. Introduction of minimum maintenance shaft concept. The system is applicable to deposits ranging from shallow, low dip angle, narrow vein, high grade to bigger, massive type vertical mineralisations accessed from the surface, preferably from the bottom of an open pit; it is also suitable as a down dip extension of an existing underground mine. The system is highly conducive to mine automation and emerging trend aimed to increase the ratio of mined $\mathrm{metal} / \mathrm{mineral}$ to mined waste. It offers substantial reduction in diesel exhaust gas emissions to the mine atmosphere.

\section{ALTERNATYWNY SYSTEM UDOSTĘPNIANIA, EKSPLOATACJI I WYDOBYWANIA PODZIEMNYCH ZŁÓŻ}

Streszczenie. W artykule zaproponowano rozważenie możliwości zastosowania nowego systemu udostępniania, eksploatacji i wydobywania złóż jako altematywnego do zwykle stosowanego, opartego na szybach pochyłych i pionowych. Zaprezentowano podstawowe korzyści wynikające z jego zastosowania oraz czynniki powodujące zmniejszenie kosztów operacyjnych wydobycia. Przedstawiono charakterystykę złóż, w których system może zostać wykorzystany. Zasygnalizowano, iż pozwala on na wprowadzenie automatyzacji gómictwa oraz zwiększenie wskaźnika wykorzystania złoża. 


\section{Introduction}

The prevailing trend over the last decades, in relatively small and shallow Australian metalliferous mines, has been to abandon vertical shaft capital access and extensively use decline for "flexibility" and easy underground access of rubber tyred mobile diesel equipment.

Generally, mining costs are governed by the ratio of excavated tonnes of ore (metal/mineral) to tonnes of excavated waste, including the waste resulting from a capital development.

With respect to the recent rather liberal use of declines as mine access, the ratio of capital waste development tonnes to mined ore tonnes (metal/mineral) has been in general excessive, especially in cases of narrow vein, high grade, smaller deposits.

Unnecessary spending of capital in a climate of declining commodity prices and the infamous reputation of the mining industry for yielding poor returns on capital is not viewed favourably by the investment community, and therefore capital for new mining projects is hard to obtain. Costs benefits resulting from a reduction of capital development in waste and the use of an inclined raisebore(s) as mine access/haulage way, are the main focus of this paper.

\subsection{Exploration}

Any justification for capital funds to get a new mining project off the ground is based on the accuracy of exploration data.

There have been numerous examples of decisions made on an incorrect geological interpretation, which have resulted in subsequent substantial financial losses or conversely, lost opportunities.

Three-dimensional aspects of an ore body like shape, mineralised zone distribution and undulation, have been widely and commonly neglected by geologists when producing resource models (and in the resource/ore reserves reconciliation process in production phase). Those parameters are almost solely responsible for unplanned waste development, poorly optimised level spacing, and subsequent ore losses and excessive dilution when stoping.

Simply speaking, to reconcile only ore tonnes, grade and metal/mineral mined against the original resource/ore body model, is far from being adequate. 


\subsection{Mine capital access}

\subsubsection{Decline access mines}

Mine decline access provides flexibility but it comes at a price, especially in view of the recent more stringent safety requirements. Quite often the quoted "flexibility" of a decline access is used to cover for lack of or bad planning practices, in both feasibility and operational stages.

Meshing of declines down to $3.5 \mathrm{~m}$ from the floor is now a normal practice, with an average cost of $\mathrm{AU} \$ 3,500 / \mathrm{m}$ in good ground conditions for a $5.3 \mathrm{~m}$ high $\mathbf{x} 5.3 \mathrm{~m}$ wide excavation accommodating a typical 30 tonne truck.

In bad ground conditions the price per meter can be substantially higher, often double, where special support like shotcrete/fibrecrete is required.

With the increasing depths of mining and further tightening on safety requirements, the price of a typical decline excavation in Australia will more than likely increase further, following the footsteps of Canadian mines as an example.

\subsubsection{Ore (metal/mineral) to capital waste ratio}

As an extreme example, a typical, small Australian narrow vein gold mine producing 100,000 tonnes of ore per year and yielding 700 to 1,400 tonnes of ore per vertical $\mathrm{m}$, would have a ratio of ore tonnes to capital development waste tonnes between $0.6-0.9$, whilst being accessed via a $5.3 \mathrm{~m}$ x $5.5 \mathrm{~m}$ decline.

Monthly production of ore on a 12 hour continuous shift roster is typically around 8,000 tonnes (or approximately $5 \times 30$ tonne trucks per shift), which is less than 0.5 of an average trucking shift, or speaking metaphorically, less than one lane of the "decline highway" is being utilised. Another words, we are excavating a big decline to efficiently hoist capital development waste.

A poignant illustration of this point is to observe a small $1.5 \mathrm{~m}^{3}$ bucket capacity LHD ( $1.5 \mathrm{~m}$ wide by $1.85 \mathrm{~m}$ high) travelling up a $5.5 \mathrm{~m}$ wide by $5.3 \mathrm{~m}$ high decline. The situation described above is not uncommon for small tonnage mines in Australia.

In response to safety concerns and in order to meet current safety requirements, a number of mines, even those relatively young (25 years of age or less), have undergone a highly expensive and disruptive decline rehabilitation programme necessitated mainly by 
deterioration of ground support or/and less stringent ground support standards applied in the past.

\subsubsection{Vertical shaft access mines}

Modern mines utilising rubber tyred diesel equipment underground and having a sole access to the surface via a vertical shaft, face a major inconvenience in lowering the dismantled equipment through the shaft for assembly in an underground workshop.

The operational inconvenience of shifting mining mobile equipment between the levels is normally addressed by an internal decline excavated in addition to the already existing shaft, which represents a doubling up on capital waste development in an often financially unjustifiable manner.

\subsubsection{Shaft ore handling system}

Rock breakers, grizzlies, ore passes and loading pockets are highly capital intensive and time consuming at their construction stage, and very expensive to maintain in operational order throughout the mine life.

\subsubsection{Shaft internal infrastructure}

Maintenance of internal structures of shafts like steel sets, guides, brattice sheets and stages, especially in a highly corrosive wet environment is very expensive and highly disruptive to production cycle.

\subsection{Level ore development and stoping}

Often due to lack of accurate geological information on all critical parameters describing the mineralised zone in three dimensions (referred to in paragraph 1.1 above) and subsequent lack of proper determination on what constitutes "ore", it has been a common occurrence to mismatch the "ore body" with the mining method and selected mining equipment.

Selection of mining method and vertical level spacing has often been based on intuition rather than on engineering determination on what produces the best Net Present Value (NPV) for a mining project from exploration to rehabilitation stage. As a result, either excessive dilution and/or ore losses have been encountered, or the mine has been over level-developed (less common situation). 
Equipment selection has been often based on availability at a particular time and not on careful planning aimed at matching the three dimensional distribution of mineralised zone along the strike and up/down dip, and producing the best NPV for the project.

\section{Proposed system}

The proposed system is shown in Figure 1 below.

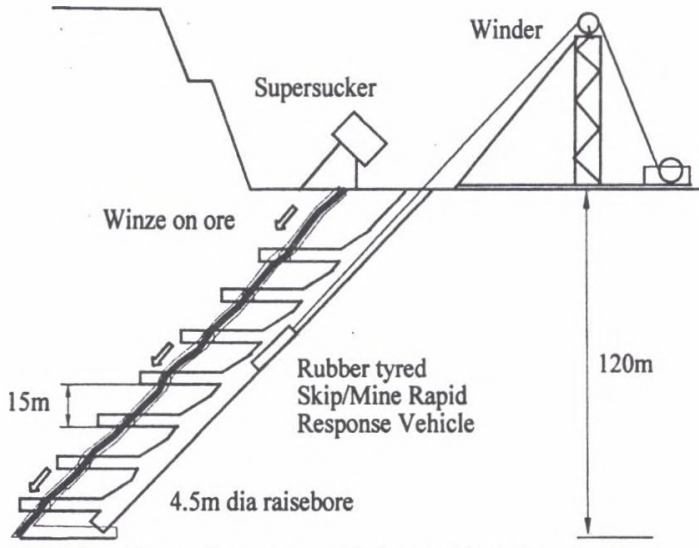

Fig. 1. Alternative access, mining and hoisting system.

\subsection{Brief description of the proposed system}

Listed below is an outline of the proposed system in sequence of construction:

1. Excavation of winze on ore with a Supersucker for superior three dimensional (3D) definition of mineralised zone in conjunction with other geological data (down to 120 vertical meters).

2. Determination of mining method and equipment selection for best NPV result.

3. Drilling of a raisebore pilot hole centrally to the strike length and close to the ore body; in case of a deeper deposit, a second parallel pilot hole needs to be drilled; both pilot holes need to be over-drilled to a final depth (600 meters down dip in this example).

4. Transportation of dismantled raisebore head down the winze.

5. Raiseboring of an inclined shaft excavation and vacuum lifting of raisebore cuttings to the surface with a Supersucker. 
6. Installation of high tonnage capacity, low speed $(2.0 \mathrm{~m} / \mathrm{s})$ transportable/semitransportable winder (West, 2000).

7. Introduction of a rubber tyred hoisting skip/Mine Rapid Response Vehicle to shift mining equipment from the surface and between the levels.

8. Excavation of level plats and a sump with drill and blast techniques and vacuum lifting of waste to the surface.

9. Excavation of shaft stockpiles/system surge stockpiles with waste hoisted in a rubber tyred skip directly loaded into it with a LHD.

10. Mining of ore with a direct loading into a skip with a LHD in a semiautomated/automated mode.

11. Down dip repetition of the above steps in $150 \mathrm{~m}$ stages as in any other development campaign.

12. Bigger and deeper deposits will require a second, parallel raisebore to cater for higher tonnage of hoisted ore and down dip increase of haulage distance; adequate winder capacity and scheduling of down dip extension work will ensure continuous and undiminished level of ore production.

\subsection{Main features}

\subsubsection{Exploration}

\subsubsection{Return to winzing}

A re-instatement of an old concept, proven and widely used in the past known as winzing, is strongly advocated. Obviously the proposed "return to winzing" has very little to do with a shovel, kibble, hard manual labour and all the bad connotations from the past. The winzing concept is outlined in Figure 2 below.

When used in combination with drilling and modern exploration techniques currently on the market, winzing is the best known method of gaining an advanced knowledge of all three dimensional parameters of a mineralised zone and reducing the risk on investment capital on a mining project.

Having many advantages, winzing as any other method has its limitations and those will be briefly discussed in this paper. 


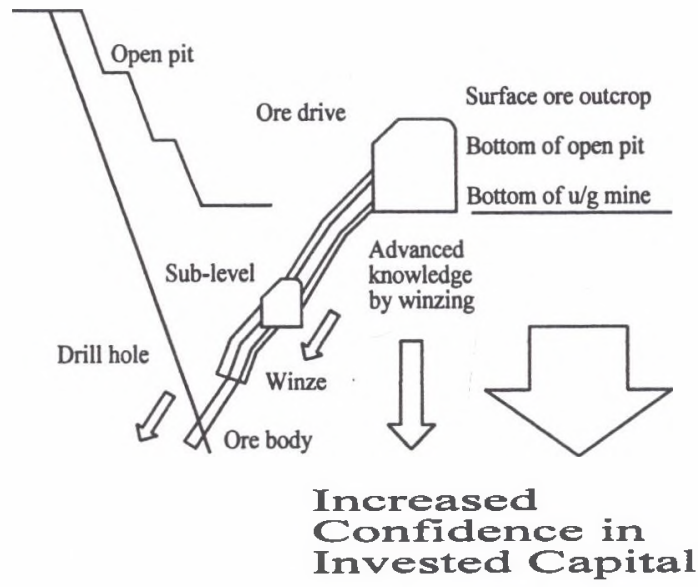

Fig. 2. Winzing concept

\subsubsection{Supersucker winzing}

It is proposed to implement modern winzing technique with a Supersucker, a giant vacuum cleaner.

Supersuckers have been widely in use in Australia in shallow shaft sinking applications over the last 25 years or so. The technique originated from South Australian opal fields, where they still remain the main ore haulage system. About 160 of them are currently in use in Coober Pedy alone, transporting millions of tonnes of material every year.

Shaft sinking depths commonly achieved in Australia reach up to $180 \mathrm{~m}$ vertically, with a $250 \mathrm{~mm}$ to $300 \mathrm{~mm}$ diameter suction pipe.

Winzing on ore with sub-levelling capabilities allows a superior bulk knowledge of mineralised zone in advance, and when used with drilling data and latest radar techniques, gives the best possible definition of all critical parameters of an ore body, namely: grade distribution and continuity, shape and undulation - all in 3D.

In addition, the benefits of bulk sampling obtained by winzing for metallurgical purposes are obvious.

\subsubsection{Operational benefits of winzing}

Apart from exploration aspects of winzing, there are a number of operational advantages of this method.

Costs of winzing, perceived by some as prohibitive, need to be viewed in a much wider context with all measurable benefits attached to it, namely: superior exploration data in 
advance, superior tool in stope design, as an excavation nearly paid for if excavated on ore (with an immediate return) and as an excavation of a multipurpose future use for either second means of egress in advance, primary ventilation in advance, longhole slot raise in advance etc.

\subsubsection{Increase of ore(metal/mineral) to capital development waste ratio}

By positioning the raisebore(s) underneath the ore body as close as geotechnically advisable, a dramatic reduction in volume of capital waste excavated is achieved, which results in an increase of ratio of ore tonnes to capital development tonnes from current 0.6 0.9 to 14 (again, typical small Australian gold mine as an extreme example).

Although the ratio of ore (metal) tonnes to capital waste development tonnes is not that low for higher tonnage decline mines, capital waste development tonnes can be reduced up to $100 \%$ (depending on a vertical level spacing) when compared to the current capital waste development required to access the ore body.

\subsubsection{Utilisation of all benefits of a raisebored excavation}

From the author's experience and to the best of his knowledge, the mining industry so far, has only taken advantage of one feature of an opening excavated with a raiseboring technique i.e. smooth surface area and shape providing low resistance for ventilating mine air (probably the least important).

It is proposed to fully capitalise on other aspects/advantages of a raisebored excavation:

1. Use an inclined raisebored excavation as a main haulage and service access for ore hoisting and transportation of mining mobile diesel equipment, materials and personnel from the surface and between the levels.

2. Lack of damage to the excavation normally caused by blasting and therefore excellent stability of the main mine access(s).

3. Geotechnically perfect and long term stable shape, requiring zero or close to zero ground support - it is assumed from experience in typical Western Australian gold mines, that a raisebore not exceeding $4.5 \mathrm{~m}$ in diameter will be stable over a long period of time without any support in good ground conditions. Periodical check scaling of the raisebore will be required. 
4. Excellent road surface requiring zero maintenance if excavated in good ground conditions (which is normally the case).

5. Close to zero maintenance access shaft due to lack of infrastructure normally installed in a conventional shaft (only winder rope rollers are installed on the raisebore's floor).

\subsubsection{Introduction of rubber tyred hoisting skip}

It is proposed to introduce a simple in construction, rubber tyred skip for ore hoisting activities.

The proposed skip, apart from winder rope rollers on the floor, will not require any infrastructure to be installed in a raisebore, which is normally an expensive capital and maintenance item in a conventional vertical or inclined shaft.

\subsubsection{Direct loading of ore into the skip}

It is proposed to totally eliminate shaft loading pockets and associated infrastructure (expensive and time consuming capital and maintenance items) by direct loading into a skip with a stope LHD.

A simple in construction, easily re-positioned chute will be used to prevent spillage.

It is proposed to operate the skip in a semi-automated (initially and later in a fully automated) mode, directly linked with stope LHDs operating on different levels to eliminate skip waiting time. Capacity surge stockpiles located near the raisebore on each level will ensure fast loading and selection of an optimum level for loading (depending on the positioning of a LHD within the stope mucking and tramming cycle in relation to the empty skip).

Recent developments in Australia in the area of laser guided autonomous LHD tramming will be highly conducive to this application with an automated stope mucking as a next step to be implemented in practical applications very soon. 


\subsubsection{Introduction of rubber tyred Mine Rapid Response Vehicle}

To accomplish swift movement of personnel, mobile diesel equipment and materials from/to the surface and between the levels (which normally presents a major inconvenience/cost in a traditional mine accessed via a shaft), it is proposed to use a simple in construction, low maintenance, rubber tyred vehicle capable of all those functions and called in this paper Mine Rapid Response Vehicle (MRRV).

Since the mass of the biggest LHD to be shifted between the levels necessitates high winder capacity, the functions of the rubber tyred skip and MRRV will be combined in the shallow stage of mine life.

When in service mode, it is proposed to operate this vehicle in a push-button, automated mode.

\subsubsection{Drastic reduction of underground mobile diesel fleet}

1. Total elimination of trucking fleet.

2. Elimination of other mobile equipment normally engaged in capital waste development activities in decline accessed mines.

3. Total elimination of underground light vehicles fleet.

\subsubsection{Utilisation of shaft's cross sectional area}

Due to lack of internal infrastructure/support, which normally occupies a lot of shaft space, the proposed system allows a superior utilisation of shaft cross sectional area for hoisting and equipment shifting,

\subsubsection{Challenges and limitations of the system}

1. Reluctance of mine managers and mine planning engineers to accept a new concept departing from a quite comfortable, "flexible" and now commonly adopted decline mine stereotype.

2. Perceived lack of flexibility when compared with a decline access.

3. Perceived complications caused by unexpected change in ore body direction, size or presence of additional ore bodies. 
4. Personnel access when excavating $150 \mathrm{~m}$ deep winze.

5. Supersucker's lifting capacity $-180 \mathrm{~m}$ vertical lifting is the limit with Supersuckers currently available.

6. Ensuring that raisebore pilot holes are straight, especially those drilled at lower angles.

7. Minimum angle of raisebore of $42^{\circ}$ to horizontal to ensure trouble free rilling of cuttings for supersucking.

8. Supporting/centralising raiseboring rods in the top part of a raisebore while extending it down dip.

9. Maximum angle of raisebore of $75^{\circ}$ to horizontal to ensure proper traction of the skip and MRRV by gravity force.

10. The proposed dismantling of raisebore head and transportation down the winze has not yet been performed in practice to the author's knowledge.

11. Limited to good ground conditions only to fully capitalise on all benefits of a raisebored excavation.

12. Diameter of the raisebore is not to exceed $4.5 \mathrm{~m}$ for local geotechnical stability.

13. Cross sectional area of the $4.5 \mathrm{~m}$ diameter risebore limits the size of the biggest LHD to an 8 cubic yard bucket capacity, which restricts the maximum tramming distance from the hoisting raisebore to approximately 400 meters.

14. For mines deeper than 100 vertical meters, a second parallel raisebore will need to be constructed (and extended down dip), to cater for uninterrupted ore hoist and increased haulage distance.

15. To the author's knowledge, rubber tyred skip and rubber tyred Mine Rapid Response Vehicle have not yet been constructed and trialed in practice in a raisebore; stable travelling of those vehicles on the floor of a risebore needs to be ensured.

\subsubsection{Safety, health and environment}

1. Fourteen (14) times reduction in exposure to rockfalls in capital development headings alone due to reduction of surface area of backs.

2. Smaller dimensions of shaft and level drives are inherently more stable and rockfall hazards will be easily identified and rectified by barring down with no need for any additional equipment (due to the lack of personnel carriers, the mine will be walked through and inspected on each shift). 
3. At least 10 times reduction in diesel equipment $\mathrm{kW}$ installed underground and diesel exhaust gas emissions to the mine atmosphere.

\subsubsection{Costs savings compared to a decline access}

The following assumptions have been made for the purpose of this comparison:

1. A mine accessed from the bottom of an open pit was considered as an example.

2. Cash flow analysis comparison was carried out for a typical medium size Australian gold mine producing 720,000 tonnes of ore at $6.0 \mathrm{~g} / \mathrm{t}$ for 139,000 ounces per year, with $15 \mathrm{~m}$ vertical level spacing and utilising longhole mining method. A mine with a life of eight years was considered with a year zero included for the initial capital development.

3. Adopted mining and milling costs, type, number and size of equipment selected, practices, productivities and personnel levels are based on current experience in Australian metalliferous mines.

4. Each 100 vertical meters of capital development will provide two years of mine production.

5. Assumed size of mined ore body: strike length $800 \mathrm{~m}$, true ore thickness $4.0 \mathrm{~m}$, dip $45^{\circ}$, grade $6.0 \mathrm{~g} / \mathrm{t}$ (in case of massive type ore bodies, $400 \mathrm{~m}$ tramming distance to the haulage raisebore).

Table 1

Summary of capital development costs for a typical decline access of 100 vertical $m$ of ore body

\begin{tabular}{|lrrr|}
\hline Decline 1 in 8 & $800 \mathrm{~m}$ & $@ \$ 3,500 / \mathrm{m}$ & $\$ 2,800,000$ \\
Decline s/piles & $6.7 \times 25 \mathrm{~m}$ & $@ \$ 3,500 / \mathrm{m}$ & 586,000 \\
Acesses * & $6.7 \times 70 \mathrm{~m}$ & $@ \$ 4,500 / \mathrm{m}$ & $2,110,000$ \\
Access s/piles & $6.7 \times 25 \mathrm{~m}$ & $@ \$ 3,500 / \mathrm{m}$ & 586,000 \\
Vent exhaust & $6.7 \times 55 \mathrm{~m}$ & $@ \$ 3,500 / \mathrm{m}$ & $1,290,000$ \\
Second egress & $40 \mathrm{~m}$ & $@ \$ 2,500 / \mathrm{m}$ & 670,000 \\
Other & $100 \mathrm{~m}$ & $@ \$ 2,500 / \mathrm{m}$ & 250,000 \\
\hline Total & & & $\$ 8,292,000$ \\
\hline
\end{tabular}


Summary of capital development costs of the proposed system

\begin{tabular}{|lrrr|}
\hline Supersucker winze & $150 \mathrm{~m}$ & $@ \$ 6,000 / \mathrm{m}$ & 900,000 \\
$4.5 \mathrm{~m}$ inclined risebore & $150 \mathrm{~m}$ & $@ \$ 6,500 / \mathrm{m}$ & 975,000 \\
Vacuum lifting of & 112,500 & $@ \$ 750 / \mathrm{m}$ & \\
cuttings & & & \\
Plats & & & \\
Plat s/piles & $6.7 \times 25 \mathrm{~m}$ & $@ \$ 6,000 / \mathrm{m}$ & $1,005,000$ \\
Raisebore head access & $6.7 \times 25 \mathrm{~m}$ & $@ \$ 3,500 / \mathrm{m}$ & 586,000 \\
Other & $25 \mathrm{~m}$ & $@ \$ 6,000 / \mathrm{m}$ & 150,000 \\
\hline Total & $100 \mathrm{~m}$ & $@ \$ 2,500 / \mathrm{m}$ & 250,000 \\
\hline
\end{tabular}

* Same mine parameters as listed under Table 1.

Table 3

Summary of cash flow for the two mine accesses considered (in million of Australian dollars)

\begin{tabular}{|lrrrr|}
\hline \multicolumn{1}{r}{ Proposed System } & & Decline & \$ Diff. & $\%$ \\
\hline Capital: & 10.7 & 0 & & \\
Winder & 1.0 & 2.6 & 1.6 & -60 \\
Surface inst. & 23.7 & 35.1 & 11.4 & -32 \\
Capital dev. & 11.2 & 26.0 & 14.8 & -57 \\
U/g mobile eq. & 1.9 & 0 & & \\
Winzing profit & 44.8 & 63.7 & -18.9 & -30 \\
Total capital & & & & \\
Operating costs (\$/t of ore): & 34 & 40 & -6 & -15 \\
Total mining & 16 & 14 & 2 & 14 \\
Milling and cart & 6.1 & 7.3 & -2.3 & -30 \\
Non cash costs/year: & & & & \\
Total cash flow (undiscounted): & 142.6 & 101.7 & 40.8 & 40 \\
Before tax & 101.7 & 71.9 & 72.6 & 40 \\
After tax @ 30\% & & & & \\
NPV @ 12\% discount rate: & 76.5 & 46.9 & 29.6 & 63 \\
Before tax & 53.6 & 31.7 & 21.9 & 69 \\
After tax & & &
\end{tabular}

A re-sale value of the winder and headframe installations has not been included in the cash flow analyses, which represents a conservative approach.

A conservative cost cut of $15 \%$ has been applied to the mine operating costs in the proposed system. The savings are based on automation of winding, automation of LHD tramming and skip loading activities, reduction of maintenance cost of mobile fleet, reduced primary ventilation power consumption and reduction of number of mine personnel. 


\section{Conclusions}

1. The proposed alternative access, mining and hoisting system offers significant safety, health and environmental benefits over a decline accessed mine due to a drastic reduction of exposure to rockfalls and reduction of underground mobile diesel fleet.

2. Supersucker winzing (in conjunction with other geological data) will deliver an unsurpassed definition of the mineralised zone in three dimensions and will enable informed mine design and planning.

3. Capitalisation on all benefits of a raisebored excavation and introduction of a rubber tyred ore hoisting skip and Mine Rapid Response Vehicle will ensure most of the essential flexibilities of a decline with a drastic reduction of capital waste development. It will also simplify ore handling system and eliminate all mobile diesel fleet involved in mining of capital development waste in a decline mine.

4. The proposed system offers $40 \%$ improvement of mine's pre-tax cash flow and $69 \%$ increase of after tax NPV.

5. Speeding up the winder to $10 \mathrm{~m} / \mathrm{s}$ will increase annual hoisting capacity to 5 million tonnes.

6. Drastic reduction of waste produced from the mine will significantly reduce disturbance to the environment and will enable mining of deposits located in populated or environmentally sensitive areas.

7. Financial comparison of the proposed system against a traditional vertical shaft access for deeper mines (where a decline access cannot be justified) is yet to be conducted - it is expected costs benefits will be substantial.

\section{REFERENCES}

Personal communications:

1. Jance, J. 1999. Principal Consulting Engineer, Western Australian Department of Minerals and Energy, Perth, Western Australia.

2. Jordan, A. 1999. Director of Jordan Mining Pty Ltd, Perth, Western Australia.

3. Maher, P. 1999. Director of Ausvac Mining Pty Ltd \& Maher Mining Contractors Pty Ltd. Kalgoorlie, Western Australia.

4. Newnham, L. 1999. Operations Manager of Byrnecut-Ruc, Kalgoorlie, Western Australia.

5. Simpson, B. 1999. Director of Vacuum Mining Pty Ltd, Perth, Western Australia. 
6. Vanajek, I. 1999. Blower Manufacturing. Coober Pedy, South Australia.

7. West, R. 2000. Manager of WA Operations, Combined Resources Engineering Pty Ltd, Perth, Western Australia.

Recenzent: prof. dr hab. inż., dr h. c. Bernard Drzęźla

\section{Podsumowanie}

Zaproponowano rozważenie zastosowania nowego systemu udostępniania, eksploatacji i wydobywania podziemnych złóż (rys. 1) jako alternatywnego do zwykle wykorzystywanego systemu udostępniania pochyłymi i pionowymi szybami. System ten pozwala przede wszystkim na zasadniczą poprawę danych badawczych, redukuje wydatki oraz umożliwia zmniejszenie górniczych kosztów operacyjnych. Koszty redukowane są poprzez:

- dokładniejsze określenie parametrów rudy przez zastosowanie w badaniach wstępnych systemu szybikowego z zasysaczem,

- znaczną redukcję strat $w$ trakcie robót udostępniających,

- pełne wykorzystanie wszystkich zalet na etapie drążenia wyrobisk,

- wprowadzenie gumowych kół w skipach oraz wozach kopalnianych,

- wprowadzenie uproszczonego systemu odstawy rudy i redukcji podziemnego transportu silnikowego,

- wprowadzenie zasady minimum ilości szybów. 